\title{
Design of Steel Column
}

\author{
K. Sathish kumar, P.Mugilvani, Anish.C,
}

\begin{abstract}
Steel moreover called as versatile material considering the way that the synthesis and internal structure to tailor Its properties can be change by us. Due to this explanation, we can make steel for paper cut, steel associate, pitiful portions of steel for incredibly sharp steels and colossal light discharge basic objective of this paper is to evaluate and design system for steel area. Focus on the lead and plan of bound area. It show the craft of concentric stacked bound column. Numerical model issues are introduced to represent compelling utilized of the strategy and tables. Tables created spread a wide scope of H-segment; notwithstanding, the general methodology applies to all areas.
\end{abstract}

Keywords: Endolithic Bacteria, Calcium Carbonate, Self-healing, Biominerlization.

\section{INTRODUCTION}

\section{A. General}

Numerous basic steel shapes appear as a prolonged shaft having a profile of a particular cross segment Structural steel is a classification of steel utilized for making development materials in an assortment of shapes.. Basic steel shapes, sizes, synthetic arrangement, mechanical properties, for example, qualities, stockpiling rehearses, and so on., are managed by norms in most industrialized nations. Most basic steel shapes, for example, I-pillars, have high second snapshots of region, which implies they are extremely solid in regard to their cross-sectional zone and hence can bolster a high burden without unnecessary drooping.. Carbon and other alloying components likes what I referenced a little while ago are going about as a solidifying specialist. From doing as such, it can avoid separations in the iron particle gem cross section from sliding past each other. By control the measure of alloying components, it can by implication control the hardness, pliability and the elasticity of the subsequent steel. By expanding the carbon content, it tends to be made harder and more grounded than iron, yet such steel is likewise less bendable than iron. Steel likewise called as a flexible material in light of the fact that the arrangement and interior structure to tailor its properties can be balanced by us. Because of this explanation, we can deliver steel for paperclips, steel spans, dainty segments of steel for extremely sharp edges and enormous bar for segment[1]-[8]

\section{Properties Of STEel}

Steel pretty much is a straight flexible material, it has a solid elasticity which caused it to can be twist into whatever shape that you like, and it additionally have a similar compressive as the rigidity. It not the same as concrete, as we realize that solid is low in rigidity however it has a solid compressive quality. In any case, with enough applied power, steel and different metals will stop to carry on flexibly and start to act plastically. At the point when a material is straightly flexible, its twisting, or strain, will be straightforwardly corresponding to the applied power and it will come back to its unique shape when the power is evacuated. A plastic material then again, will for all time disfigure without breaking.In reality, we can't found such thing as flawlessly flexible or plastic material. Material preferences steel, the elasticity and the compressive quality are worried by basic designers. At the point when steel arrives at its yield quality, It began to stretch and change from versatile to plastic conduct. When there is more power that applied on steel, it will made it arrives at its definitive elasticity and in the long run it will break. Because of the high rigidity that steel has, basic specialists exploit in their structure. In some Natural fiascos likes seismic tremor or major auxiliary disappointment, the properties which steel has is extremely valuable since it enables the structure to ingest additional heap. For those material that excessively fragile, it will break rather than stretch, it perhaps will make the structure crash down, however for material preferences steel, when the structure is demolished, yet its plastic conduct permits time for escape. The shapes accessible are portrayed in many distributed models around the world, and various master and exclusive cross segments are likewise accessible. A steel I-bar, for this situation used to help timber joists in a house.I-pillar (I-formed cross-segment - in Britain these incorporate Universal Beams (UB) and Universal Columns (UC); in Europe it incorporates the IPE, HE, HL, HD and different areas; in the US it incorporates Wide Flange (WF or W-Shape) and H sections),Z-Shape (a large portion of a spine fit as a fiddle (Hollow auxiliary segment otherwise called SHS (basic empty segment) and including square, rectangular, roundabout (pipe) and curved cross sections)Angle (L-molded cross-section), Structural channel, or C-shaft, or C cross-segment, Tee (T-formed cross-section), Rail profile (awry I-beam), Railway rail, Flanged T rail, Grooved rail, Bar, a bit of metal, rectangular cross separated (level) and long, yet not all that wide in order to be known as a sheet, Rod, an adjust or square and long bit of metal, see additionally rebar and dowel.[9]-[17]

\section{B.Types Of Steel Column}

-Laced Column

-Battened Column.

Revised Manuscript Received on December 11, 2019

K. Sathish kumar, Asistant Professor, Department Of Civil Engineering,,Bharath Institution of Higher Education And Research,TamilNadu, India Email sathish_4549@yahoo.co.in P.Mugilvani, Assistant Professor,,Department Of Civil Engineering,,Bharath Institution Of Higher Education And Research,TamilNadu, India .Email: mugilvanipalanivel@gmail.com

Anish.C, Assistant Professor, Department Of Civil Engineering,,Bharath Institution of Higher Education And Research,TamilNadu, India Email anishdavidpaul@gmail.com 


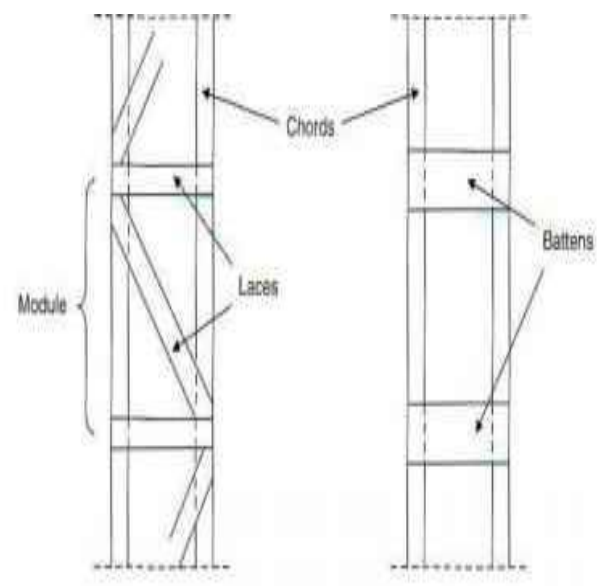

(a)

(b)

\section{Laced Battened}

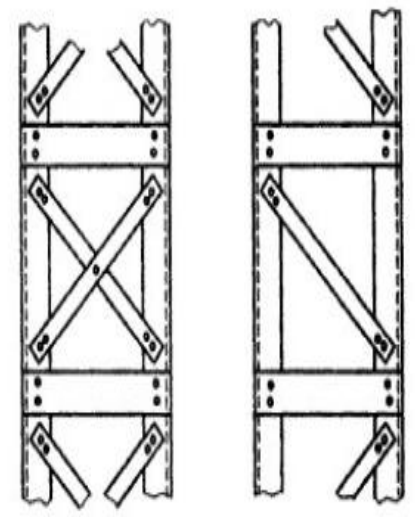

Double Laced and Single Laced System Combined with Cross Numbers

\section{Laced built-up column}

There are enormous quantities of bound section setup that might be considered. Be that as it may, the $\mathrm{N}$-shape and $\mathrm{V}$-shape game plan of lacings are ordinarily used.The $\mathrm{N}$-shape course of action of lacings, as appeared in Fig. can be considered as the most proficient support setup, for regular casings in mechanical structures. The trap of the $\mathrm{N}$-shape includes diagonals and posts that meet at a similar point on the line tomahawks. This game plan decreases the length of the pressure harmonies and diagonals. It is normally utilized Ina outlines with a significiant uniform compressive power.

The V-shape (single bound) plan of binding builds the length of the pressure harmonies and diagonals and gives a decrease of clasping opposition of the individuals. The plan is utilized in outlines with low compressive power. The $\mathrm{X}$ - shape (twofold bound) design are not commonly utilized in structures as a result of the expense and the multifaceted nature of creation. [18]-[27]

The distinction these two sorts of developed segments originates from the method of association of the web individuals (lacings and secures) to the harmonies. The main kind contains diagonals (and perhaps swagger) planned with stuck closures. The subsequent sort includes secures with fixed finishes to the harmonies and working as a rectangular board. The latency of the developed segment increments with the separation between the harmony tomahawks. The expansion in solidness is balanced the weight and cost increment in association between individuals. Developed sections furnish generally light structures with a huge dormancy. For sure, the situation of the harmony, a long way from the centroid of the developed segment, is extremely helpful in creating an incredible dormancy. These individuals are commonly expected for tall structures for which the level uprooting are constrained to low esteem (for example .segments supporting crane braces)

\section{OBJECTIVES}

1. To find out about the structure criteria and detail of steel bound segment.

2. To plan different sorts of steel segments.

3. To comprehend stacking conditions for embracing steel bound segment.[28]-[34]

\section{ADVANTAGES OF STEEL STRUCTURES}

1) By utilizing blasted associations, steel structures can be effectively disassembled shipped to different locales rapidly. 2) If Joints are taken consideration, it is the best water and gas safe structure. Consequently can be utilized for making water tanks too.

\section{DISADVANTAGES OF STEEL STRUCTURES}

1) It is powerless to consumption.

2) Maintenance expense is high, since it needs painting to avert consumption.

3) Steel individuals are exorbitant.

4) Steel has little opposition against fire when contrasted with concrete. Nearly from 600-700C portion of steel quality diminished.

5) Steel can't be shape toward any path you need. It must be utilized in structures in which areas initially exists.

6) If steel loses its pliability property, at that point odds of weak cracks increment

\section{METHODOLOGY}

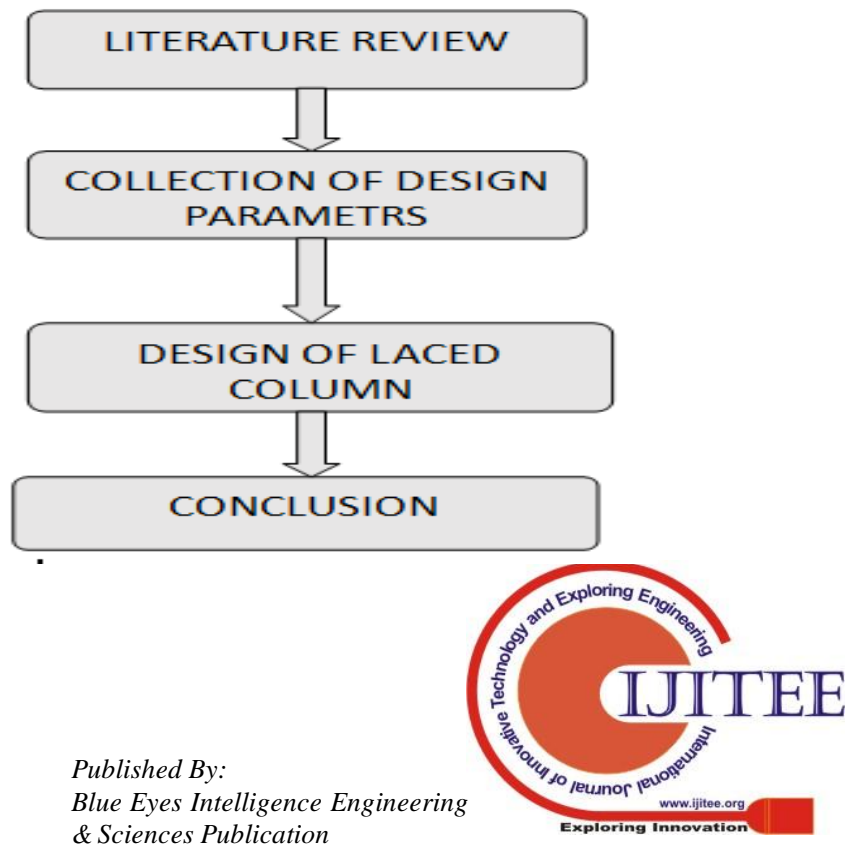




\section{DESIGN PARAMETER}

i.Length of column

ii.Factored load

iii.Support condition : Restrained in position but not in direction of each end.

iv.Lacing : Single lacing

v.Connection bolt connection

vi. Column shall consist of two channels placed back to back with suitable spacing.

\section{RESULTS}

Given Data....

Length of column $=10 \mathrm{~m}$

Factored load $=1200 \mathrm{KN}$

Support Conditions; Restrained in position but not in direction of each end.

Lacing ; Single lacing

Connection ; Bolt connection

STEP - 1

Assuming approximate design compressive stress $=160$ $\mathrm{N} / \mathrm{mm}^{2}$

Approximate sectional area required $=1200 \times 10^{3} / 160=$ $7000 \mathrm{~mm}^{2}$

\section{STEP - 2}

Properties of section; From Steel Table, Choose two channels ISMC 350, Properties of one ISMC 350,

(From Page 87, Table 17, Steel Table) Area $=4564 \mathrm{~mm}^{2}$ (For

Single) Area of composite section, A $=2 \times 4564$ (For Double) $=9128 \mathrm{~mm}^{2} \mathrm{r}_{\mathrm{zz}=} 118.1$

Based on the effective slenderness ratio of the laced column

$$
\begin{aligned}
& =1.05 \mathrm{k} \mathrm{L} / \mathrm{r}_{\mathrm{z}} \\
& =1.05 \times 10 \times 10^{3} / 118.1 \\
& =88.91
\end{aligned}
$$

For buckling class $\mathrm{C}$ design compressive stress corresponding to the above slenderness ratio

$\mathrm{f}_{\mathrm{cd}}=136-(136-121)(88.91-80) / 10$

$\mathrm{F}_{\mathrm{cd}}=149.365$ (From code book IS 800, page 42)

Design Compressive Strength of column

$\mathrm{Pd}=\mathrm{f}_{\mathrm{cd}} \times \mathrm{A}$

$=149.36 \times 9128 \times 10^{-3}$

$=1363.35 \mathrm{KN}>1000 \mathrm{KN}$

\section{STEP - 3}

\section{Spacing of Channels}

Let the channels to be provided back to back, let $\mathrm{S}$ be the distance the backs of the channels

For the condition

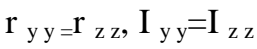

$=2\left(\mathrm{I}_{\mathrm{y} y}+\mathrm{A}\left(3 / 2+\mathrm{C}_{\mathrm{yy}}\right)^{2}\right.$

$=2\left(310.8 \times 10^{4}+4564(\mathrm{~S} / 2+23.6)^{2}\right.$

$=2 \times 6362 \times 10^{4}$

$=4564(\mathrm{~S} / 2+23.6)^{2}$

$=6051.8 \times 10^{4}$
$=\mathrm{S} / 2+23.6$

$=115.15$

$\mathrm{S}=183.1 \mathrm{~mm}$

STEP - 4

Lacing bars

The Lacing bars to be provided at 45 with the horizontal distance $\mathrm{b} / \mathrm{w}$ bolt line

$$
\begin{aligned}
& =185+50+50 \\
& =285 \mathrm{~mm} .
\end{aligned}
$$

\section{STEP - 5}

Spacing of bar

Let $\mathrm{a}_{1}=$ Spacing of bar (Horizontal bolt line $\times \operatorname{Tan} 45^{\circ}$ )

$$
\begin{aligned}
& =\left(285 \tan 45^{\circ}\right) 2 \\
& =570 \mathrm{~mm} .
\end{aligned}
$$

For one channel, $\mathrm{a}_{1} / \mathrm{r}_{\mathrm{y}}=570 / 26.1$

$=21.84<50$

Check,

0.7 times the slenderness ratio for the column

$$
\begin{aligned}
& =0.7 \times 71.13 \\
& =49.7
\end{aligned}
$$

Therefore, $\mathrm{a}_{1} / \mathrm{r}_{\mathrm{y}}<0.7$ times the slenderness ratio of the column.

Transverse shear to be resisted $=\mathrm{V}_{\mathrm{t}}=2.5 \%$ of axel force

$$
\begin{aligned}
& =2.5 \times 1000 \times 10^{3} \div 100 \\
& =25000 \mathrm{~N}
\end{aligned}
$$

Let $\tau=$ Compressive force in one lacing bars

$$
2 \tau \operatorname{Cos} 45^{\circ}=25000
$$

$\tau=17677 \mathrm{~N}$

\section{STEP - 6}

Minimum width of lacing bars $=3 \times$ Diameter of bolt

$$
\begin{aligned}
& =3 \times 16 \\
& =48 \mathrm{~mm} .
\end{aligned}
$$

Provided $50 \mathrm{~mm}$ wide of lacing bars $=1 / 40($ Effective

length of lacing bar)

$$
\begin{aligned}
& =1 / 40(285 \sqrt{ } 2) \\
& =10.1 \mathrm{~mm}
\end{aligned}
$$

Provided 50mm @ 12mm lacing bars

STEP - 7

Minimum radius of gyration of lacing bars

$$
\begin{aligned}
& \mathrm{r}=\sqrt{\mathrm{I}} / \mathrm{A} \\
& =\sqrt{ } \mathrm{bt}^{3} / 12 \div \mathrm{bt} \\
& =\mathrm{t} \div \sqrt{ } 12 \\
& =12 \div \sqrt{ } 12 \\
& =3.464 \mathrm{~mm}
\end{aligned}
$$

Slenderness ratio of lacing bars $=285 \sqrt{2} / 3.464$

$$
=116.4<145
$$

STEP - 8

For buckling class 'c' design compressive stress corresponding to this slenderness ratio,

$$
\mathrm{F}_{\mathrm{cd}}=87.62
$$

$\mathrm{N} / \mathrm{mm}^{2}$ 


\section{Design of Steel Column}

(Refers IS,800-2007,Pg-42)

Design compressive strength $=87.62 \times 50 \times 12$

$$
=57572 \mathrm{~N}>22097 \mathrm{~N}
$$

Design tensile strength against rupture

$$
\begin{aligned}
& =0.9 \mathrm{~A}_{\mathrm{n}} \mathrm{f}_{\mathrm{u}} / \gamma_{\mathrm{mi}} \\
& =0.9(50-18) \times 12 \times 410 / 1.25 \mathrm{~N} \\
& =113357 \mathrm{~N}
\end{aligned}
$$

Design tensile strength of lacing bar

$=\mathrm{A}_{\mathrm{g}} \mathrm{f}_{\mathrm{u}} / \gamma_{\mathrm{mo}}$

$=50 \times 12 \times 250 / 1.1$

$=136363 \mathrm{~N}$

Therefore, Design tensile strength of lacing bar,

$=113357 \mathrm{~N}>22097 \mathrm{~N}$

Design shear strength of $16 \mathrm{~mm}=2\left(\mathrm{f}_{\mathrm{u}} \cdot \mathrm{A}_{\mathrm{n}} / \sqrt{ } 3 \gamma \mathrm{m}_{\mathrm{b}}\right)$

(Since one bolt passes through two lacing bars, the bolt is taken to be double shear)

$$
\begin{aligned}
& =2\left(400 \times 0.78 \times \text { л } \times 16^{2} / \sqrt{ } 3 \times 1.25 \times 4\right) \mathrm{N} \\
& =57950 \mathrm{~N}
\end{aligned}
$$

Design bearing strength of bolt

$=2.5 \mathrm{~K}_{\mathrm{b}} \mathrm{d} \mathrm{t} \mathrm{f}_{\mathrm{u}} / \gamma_{\mathrm{mb}}$

$=2.5(1) 16 \times 12 \times 400 / 1.25 \mathrm{~N}$

$=153600 \mathrm{~N}$

Design strength of bolt $=57950$

No. of bolt required $\quad=22097 / 57950$

$=1$ bolt

Plates;

A tie plate must be provided at each end of the laced column Effective Depth of a tie plate;

Not less than the distance between the centroids of the main members

$=185+2(23.6)$

$=232.2 \mathrm{~mm}$

Total depth of the tie plate $=232.2+2(30)$

$$
=292.2 \mathrm{~mm} \text { say } 300 \mathrm{~mm}
$$

Total width of the tie plate $=185+2(90)$

$=365 \mathrm{~mm}$

Thickness ofthe plate $=1 \times(285) / 50$

$=5.7 \mathrm{~mm}$ say $6 \mathrm{~mm}$

\section{CONCLUSION}

A steel laced column has been designed in such a way that it fulfils all the needs and requirement of future development. In this project we have gained more knowledge of how to design steel column with different connection and also studied about different types of column connection.

At the end of this project we are in the through knowledge of reinforcement detailing and effective usage of IS-800-2007 and steel table.

\section{REFERENCES}

1. Iyappan L., Dayakar P., Identification of landslide prone zone for coonoortalukusing spatial technology, International Journal of Applied Engineering Research,V-9,I-22,PP-5724-5732,Y-2014.
2. Kumar J., Sathish Kumar K., Dayakar P.,Effect of microsilica on high strength concrete, International Journal of Applied Engineering Research,V-9,I-22,PP-5427-5432,Y-2014.

3. Dayakar P., Vijay Ruthrapathi G., Prakesh J., Management of bio-medical waste, International Journal of Applied Engineering Research,V-9,I-22,PP-5518-5526,Y-2014.

4. Swaminathan N., Dayakar P., Resource optimization in construction project, International Journal of Applied Engineering Research,V-9,I-22,PP-5546-5551,Y-2014.

5. Venkat Raman K., Dayakar P., Raju K.V.B.,An experimental study on effect of cone diameters in penetration test on sandy soil, International Journal of Civil Engineering and Technology,V-8,I-8,PP-1581-1588,Y-2017.

6. Saritha B., Chockalingam M.P.,Photodradation of malachite green DYE using TIO2/activated carbon composite,International Journal of Civil Engineering and Technology,V-8,I-8,PP-156-163,Y-2017

7. Shendge R.B., Chockalingam M.P., Saritha B., Ambica A.,Swat modelling for sediment yield: A case study of Ujjani reservoir in Maharashtra, India,International Journal of Civil Engineering and Technology,V-9,I-1,PP-245-252,Y-2018

8. Chockalingam M.P., Balamurgan V.,Modernisation of an existing urban road-sector in Chennai, a case study report,International Journal of Civil Engineering and Technology,V-8,I-8,PP-1457-1467,Y-2017

9. Saritha B., Chockalingam M.P.,Adsorption study on removal of basic dye by modified coconut shell adsorbent, International Journal of Civil Engineering and Technology,V-8,I-8,PP-1370-1374,Y-2017

10. Saritha B., Chockalingam M.P.,Adsorptive removal of heavy metal chromium from aqueous medium using modified natural adsorbent,International Journal of Civil Engineering and Technology,V-8,I-8,PP-1382-1387,Y-2017

11. Chockalingam M.P., Palanivelraja S.,Retrospective analysis of a theoretical model used for forecasting future air quality near the north Chennai thermal power plant,International Journal of Civil Engineering and Technology,V-8,I-8,PP-1457-1467,Y-2017

12. Saritha B., Chockalingam M.P.,Photodegradation of methylene blue dye in aqueous medium by Fe-AC/TiO2 Composite,Nature Environment and Pollution Technology,V-17,I-4,PP-1259-1265,Y-2018

13. Shendge R.B., Chockalingam M.P., Kaviya B., Ambica A.,Estimates of potential evapotranspiration rates by three methods in upper Bhima Basin, In Maharashtra, India,International Journal of Civil Engineering and Technology,V-9,I-2,PP-475-480,Y-2018

14. Shendge R.B., Chockalingam M.P.,The soil and water assessment tool for Ujjani Reservoir,International Journal of Mechanical Engineering and Technology,V-9,I-2,PP-354-359,Y-2018

15. Shendge R.B., Chockalingam M.P.,A review on soil and water assessment tool,International Journal of Mechanical Engineering and Technology,V-9,I-2,PP-347-353,Y-2018

16. Sachithanandam P., Meikandaan T.P., Srividya T.,Steel framed multi storey residential building analysis and design,International Journal of Applied Engineering Research,V-9,I-22,PP-5527-5529,Y-2014

17. Meikandaan T.P., Ramachandra Murthy A.,Study of damaged RC beams repaired by bonding of CFRP laminates,International Journal of Civil Engineering and Technology,V-8,I-2,PP-470-486,Y-2017

18. Meikandaan T.P., Ramachandra Murthy A.,Retrofittng of reinforced concrete beams using GFRP overlays,International Journal of Civil Engineering and Technology,V-8,I-2,PP-423-439,Y-2017

19. Meikandaan T.P., Ramachandra Murthy A.,Flexural behaviour of RC beam wrapped with GFRP sheets,International Journal of Civil Engineering and Technology,V-8,I-2,PP-452-469,Y-2017

20. Meikandaan T.P., Murthy A.R.,Experimental study on strengthening of rc beams using glass Fiber,International Journal of Civil Engineering and Technology,V-9,I-11,PP-959-965,Y-2018

21. Meikandaan T.P., Hemapriya M.,Use of glass FRP sheets as externa flexural reinforcement in RCC Beam,International Journal of Civil Engineering and Technology,V-8,I-8,PP-1485-1501,Y-2017

22. Saraswathy R., Saritha B.,Planning of integrated satellite township at Thirumazhisai,International Journal of Applied Engineering Research,V-9,I-22,PP-5558-5560,Y-2014

23. Saritha B., Ilayaraja K., Eqyaabal Z.,Geo textiles and geo synthetics for soil reinforcement,International Journal of Applied Engineering Research,V-9,I-22,PP-5533-5536,Y-2014

24. Ambica A., Saritha B., Changring G., Singh N B., Rajen M., Salman Md.,Analysis of groundwater quality in and around Tambaram taluk, Kancheepuram district,International Journal of Civil Engineering and Technology,V-8,I-8,PP-1362-1369,Y-2017

25. Arunya A., Sarayu K., Ramachandra Murthy A., Iyer N.R.,Enhancement of durability properties of bioconcrete incorporated with nano silica,International Journal of Civil Engineering 
Technology,V-8,I-8,PP-1388-1394,Y-2017

26. Ilayaraja K., Krishnamurthy R.R., Jayaprakash M., Velmurugan P.M., Muthuraj S.,Characterization of the 26 December 2004 tsunami deposits in Andaman Islands (Bay of Bengal, India),Environmental Earth Sciences,V-66,I-8,PP-2459-2476,Y-2012

27. Ilayaraja K.,Morphometric parameters of micro watershed in Paravanar sub-basin, Cuddalore District,International Journal of Civil Engineering and Technology,V-8,I-8,PP-1444-1449,Y-2017

28. Ilayaraja K., Singh R.K., Rana N., Chauhan R., Sutradhar N.,Site suitability assessment for residential areas in south Chennai region using remote sensing and GIS techniques,International Journal of Civil Engineering and Technology,V-8,I-8,PP-1468-1475,Y-2017

29. Ilayaraja K., Reza W., Kumar V., Paul S., Chowdhary R.,Estimation of land surface temperature of Chennai metropolitan area using Landsat images,International Journal of Civil Engineering and Technology,V-8,I-8,PP-1450-1456,Y-2017

30. Chitra R.,Experimental study on beam using steel fiber and latex,International Journal of Civil Engineering and Technology,V-8,I-8,PP-1395-1403,Y-2017

31. Chitra R.,Analysis of traffic and management at Kovilambakkam intersection,International Journal of Civil Engineering and Technology,V-8,I-8,PP-1433-1443,Y-2017

32. Aswathy M.,Experimental study on light weight foamed concrete,International Journal of Civil Engineering and Technology,V-8,I-8,PP-1404-1412,Y-2017

33. Aswathy M.,Wastewater treatment using constructed wetland with water lettuce (Eichornia Crasipies),International Journal of Civil Engineering and Technology,V-8,I-8,PP-1413-1421,Y-2017

34. Kiruthiga K., Anandh K.S., Gunasekaran K, Assessment of influencing factors on improving effectiveness and productivity of construction engineers, 2015, International Journal of Applied Engineering Research, V - 10,I -17,p -13849-13854.

\section{AUTHORS PROFILE}

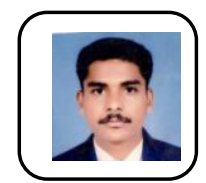

K. Sathish kumar, Asistant Professor, Department Of Civil Engineering,,Bharath Institution of Higher Education And Research,TamilNadu, India

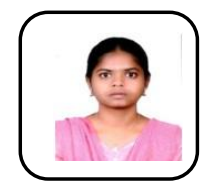

P.Mugilvani, Assistant Professor,,Department Of Civil Engineering,,Bharath Institution Of Higher Education And Research,TamilNadu, India .

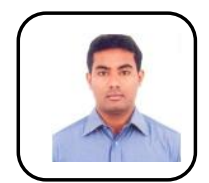

Anish.C Assistant Professor,,Department Of Civil Engineering,,Bharath Institution Of Higher Education And Research,TamilNadu, India . 